\title{
Antifungal Potential of Three Natural Oils and Their Effects on the Thermogravimetric and Chromatic Behaviors When Applied to Historical Paper and Various Commercial Paper Sheets
}

\author{
Maisa M. A. Mansour, ${ }^{a}$ Mohamed Z. M. Salem, ${ }^{b}$ Rushdya Rabee Ali Hassan, ${ }^{\text {a }}$ \\ Hayssam M. Ali, ${ }^{\mathrm{c}, \mathrm{d}, *}$ Dunia A. Al Farraj, ${ }^{\mathrm{c}}$ and Mohamed S. Elshikh ${ }^{\mathrm{c}}$
}

\begin{abstract}
Three natural extracted oils from Citrus reticulata peels, $C$. aurantifolia leaves, and Linum usitatissimum (linseeds) were used as antifungal agents against the growth of Aspergillus flavus and Penicillium chrysogenum. The following main compounds (determined via gas chromatography-mass spectrometry) were found. The essential oil (EO) from C. aurantiifolia leaves contained limonene (22.96\%), geranyl acetal $(13.53 \%)$, and geraniol acetate $(13.33 \%)$; the $n$-hexane oil from $C$. reticulata peels contained methyl-13-cyclopentyltridecanoate $(16.74 \%)$, and $D$-limonene (16.06\%); and linseed oil contained linoleic acid (27.36\%), and oleic acid (19.01\%). The inhibition of fungal growth significantly was reached $100 \%$ against $A$. flavus at all tested $C$. aurantifolia leaf EO concentrations and at a concentration of $2000 \mu \mathrm{L} / \mathrm{mL}$ for linseeds oil. The growth inhibition reached $100 \%$ against $P$. chrysogenum with $C$. aurantifolia leaf EO concentrations of $125-2000 \mu \mathrm{L} / \mathrm{mL}$. Citrus reticulata peel EO had $100 \%$ growth inhibition of $P$. chrysogenum at concentrations of $2000 \mu \mathrm{L} / \mathrm{mL}$ and $1000 \mu \mathrm{L} / \mathrm{mL}$, while linseeds oil had $100 \%$ growth inhibition at $2000 \mu \mathrm{L} / \mathrm{mL}$. Thermogravimetric analysis showed that $C$. aurantifolia EO yielded the greatest thermal stability and color change protection to cotton pulp, while linseed oil was found to protect wood pulpbased and historical papers.
\end{abstract}

Keywords: Antifungal potential; Chromatic behaviors; Natural oils; Paper; pH, TGA; FTIR

Contact information: a: Conservation Department, Faculty of Archaeology, Cairo University, Giza 12613 Egypt; b: Forestry and Wood Technology Department, Faculty of Agriculture (EL-Shatby), Alexandria University, Alexandria 21545 Egypt; c: Botany and Microbiology Department, College of Science, King Saud University, P.O. Box 2455, Riyadh 11451 Saudi Arabia; d: Timber Trees Research Department, Sabahia Horticulture Research Station, Horticulture Research Institute, Agriculture Research Center, Alexandria 21526 Egypt; *Corresponding author: hayhassan@ksu.edu.sa

\section{INTRODUCTION}

Fungi are the main deterioration agents for wood, wood products, paper, historical manuscripts, leathers, and other heritage artifacts. They degrade the polysaccharide components and cause cell wall degradation or discoloration of organic materials (da Silva et al. 2006; Zyani et al. 2009; Sequeira et al. 2014; Hassan and Mansour 2018; Abo Elgat et al. 2020a; Hassan et al. 2020a; Mansour et al. 2020a; Mansour et al. 2020b; Salem et al. 2020a). Most of these fungi, including Aspergillus flavus and Penicillium chrysogenum, cause damage to historical papers in practice (Ljaljević-Grbić et al. 2013; Pinheiro et al. 2019).

Medicinal/aromatic plants and edible seeds are good sources for natural oils and 
extracts with potential biological activities against different groups of pathogens, e.g., antibacterial (Abbassy et al. 2020; Ashmawy et al. 2020a, b), antifungal (El-Hefny et al. 2019; Salem et al. 2019a,b; Behiry et al. 2020; Mansour et al. 2020a; Mohamed et al. 2020a, b; Salem et al. 2020b), and insecticidal (Hussein et al. 2017; Hamada et al. 2018; El-Sabrout et al. 2019; Hamad et al. 2019; Salem et al. 2020b), as well as providing antioxidant properties (Salem et al. 2016a; Elansary et al. 2017; El-Hefny et al. 2018; AlHuqail et al. 2019; Okla et al. 2019a). In the present work, extracted oils from Citrus aurantifolia, C. reticulata, and Linum usitatissimum were used.

The peel oils of many species of Citrus showed the presence of limonene as the primary compound (Moufida and Marzouk 2003; Golmohammadi et al. 2018; Okla et al. 2019b; Abo Elgat et al. 2020b), which provides strong antifungal activity against $A$. flavus (Velázquez-Nuñez et al. 2013). The essential oil from $C$. aurantifolia showed strong inhibitory effects towards Aspergillus parasiticus and aflatoxins production (Rammanee and Hongpattarakere 2011). The primary compound in C. aurantifolia leaves essential oil, $D$-limonene, showed promising antibacterial activity against Staphylococcus aureus and Escherichia coli strains with excellent in vitro antioxidant activity (Al-Aamri et al. 2018). Essential oils and extracts from $C$. aurantifolia are known to exhibit important biological activities against several pathogens, e.g., Staphylococcus aureus, Escherichia coli, Klebsiella pneumonia, Aspergillus niger, and Candida albicans, such as antiaflatoxigenic and anticancer properties (Aibinu et al. 2007; Razzaghi-Abyaneh et al. 2009; Pathan et al. 2012; Narang and Jiraungkoorskul 2016). Limonene (46.7\%), as well as other compounds such as geranial, neral, and geranyl, were identified in the oil extracted from Citrus reticulata Blanco, which all show promising antifungal activity (Chutia et al. 2009). The peel oil from $C$. reticulata proved to be more toxic to Sitophylus zeamais adults than $C$. aurantiifolia oil (Fouad and da Camara 2017).

Flaxseed (Linum usitatissimum L., Linaceae family) is a good source of $\alpha$-linolenic acid (an omega-3 fatty acid), as well as phenolic compounds, peptides, cyanogenic glycosides, alkaloids, polysaccharides, proteins, and fixed oil, which promises several health benefits (Hall et al. 2006; Krajčová et al. 2009; Bayrak et al. 2010; Goyal et al. 2014; Shim et al. 2014; Chauhan et al. 2015). The unsaturated fatty acids and lignans are the two primary groups of metabolites in flaxseed that exhibit antimicrobial activities (Paiva et al. 2010; Fadzir et al. 2018). The extracts derived from flaxseeds have been suggested to be effective in prohibiting the growth of Escherichia coli, Salmonella paratyphii, Lactobacillus, Staphylococcus aureus, Proteus vulgaris, Klebsiella pneumoniae, and Saccharomyces cerevisiae (Narender et al. 2016). Flaxseed oil was applied as a constrictive bioantifungal and exhibited average insecticidal properties (Kaithwas and Majumdar 2013). The $n$-hexane extract showed promising antimicrobial activity against $S$. aureus, S. epidermis, Enterococcus faecalis, Escherichia coli, and $K$. pneumoniae (Al-Mathkhury et al. 2016). The extracted oligosaccharides from flaxseed were found to be able to control the growth of Alternia alternata and Alternia solani (Guilloux et al. 2009).

This study was carried out in order to investigate in vitro the antifungal potency of extracted oils from Citrus aurantifolia leaves, Citrus reticulata peels, and Linum usitatissimum seeds against two fungal strains, Aspergillus flavus (acc\#MH355958) and Penicillium chrysogenum (acc\#MH352451). In this context, this is the first time these extracts have been evaluated for their effects on the thermogravimetric and chromatic properties of historical papers in comparison to paper made from the pulp of softwood and cotton. 


\section{EXPERIMENTAL}

\section{Preparation of the Natural Oils}

The oil from Citrus aurantifolia leaves was extracted via the hydrodistillation method, where approximately $150 \mathrm{~g}$ of small pieces of leaves were put in $2 \mathrm{~L}$ flask containing $1500 \mathrm{~mL}$ of distilled water then connected to a Clevenger unit and heated for 3 $\mathrm{h}$ under refluxing (Abdelsalam et al. 2019). The obtained essential oil was kept dry in an Eppendorf tube.

Peels from C. reticulata were collected as the byproduct from fruits and linseeds (Linum usitatissimum L.) were purchased from an herbarium store located in Alexandria City, Egypt. Approximately $250 \mathrm{~g}$ of ripened linseeds and C. reticulata peels, in form of small pieces, were soaked (separately) in $200 \mathrm{~mL}$ of n-hexane solvent for $24 \mathrm{~h}$. After the extraction process, the materials were filtered through a cotton plug using filter paper (Whatman No. 1), to removal any solid residues and to obtain the dissolved oils in n-hexane solvent (Ashmawy et al. 2020b). The solvent was evaporated, and the oils were obtained and preserved at $4{ }^{\circ} \mathrm{C}$ in a refrigerator until needed.

\section{Chemical Analysis of the Oils}

The oil extracts collected from ripened flax seeds and Citrus reticulata peels via nhexane solvent extraction were analyzed for their chemical constituents with a Trace GC Ultra-ISQ mass spectrometer (Thermo Scientific, Austin, TX) with a direct capillary column TG-5MS (30 $\mathrm{m} \times 0.5 \mathrm{~mm} \times 0.25 \mu \mathrm{m}$ film thickness) apparatus at the Atomic and Molecular Physics Unit, Experimental Nuclear Physics Department, Nuclear Research Centre, Egyptian Atomic Energy Authority (Inshas, Cairo, Egypt). The column oven temperatures and the chemical separation and identification conditions can be found in the study by Salem et al. (2019a). The conditions used to separate and identify the chemical compounds in the essential oil from the Citrus aurantifolia leaves can be found in the study by Okla et al. (2019b). Xcalibur 3.0 data system in the GC-MS with its values of threshold were used to confirm that all the mass spectra of the identified compounds were attached to the library. Furthermore, the measurement indices of Standard Index (SI) and Reverse Standard Index (RSI) with values $\geq 650$ were used to confirm the identified compounds (Abdelsalam et al. 2019; Salem et al. 2019a,b; Ashmawy et al. 2020a,b; Mohamed et al. 2020a,b; Behiry et al. 2020).

\section{Antifungal Activity of the Oils}

The three oils were prepared at concentrations of 2000,1000,500,250,125, and $62 \mu \mathrm{L} / \mathrm{mL}$ by dissolving them $10 \%$ dimethyl sulfoxide (DMSO) followed by $0.5 \mathrm{~mL}$ of tween 80, which was used to emulsify the carrier oils in the solvent (Salem et al. 2016b, 2019b). Potato dextrose agar (PDA) medium was used to grow the two tested fungi, Aspergillus flavus (acc\#MH355958) and Penicillium chrysogenum (acc\#MH352451), at $26{ }^{\circ} \mathrm{C}$ at a relative humidity of $65 \pm 5 \%$. The PDA medium was sterilized, and then the concentrated oils were added to the PDA medium and poured into sterilized Petri dishes. For each fungus type, fungal mycelial (7-day-old culture) discs, with a diameter of $0.5 \mathrm{~cm}$, were put directly on the surface of the treated medium at the center of the Petri dishes. All the inoculated plates were incubated at $26^{\circ} \mathrm{C}$, and after the control treatment had finished growing (inoculated plates did not contain plant oils), the fungal diameter growth was measured in triplicate (Salem et al. 2017). The percentage of growth inhibition (GI) was calculated according to Eq. 1, 


$$
\mathrm{GI} \%=\left[\left(G_{1}-G_{2}\right) / G_{1}\right] \times 100
$$

where the GI is the mycelial growth inhibition (\%), and $G_{1}$ and $G_{2}$ are the average diameters $(\mathrm{mm})$ of the fungal colonies of the control (10\% DMSO) and treatment, respectively. The minimum inhibitory concentrations (MICs) of the studied oils were measured as they were prepared at concentrations of $2 \mu \mathrm{L} / \mathrm{mL}$ to $62 \mu \mathrm{L} / \mathrm{mL}$, using the broth dilution method according to CLSI (2008).

\section{TGA Measurements}

Source of papers

Paper samples with approximate dimensions of $7 \mathrm{~cm} \times 15 \mathrm{~cm}$ with a $0.05 \mathrm{~mm}$ thickness were selected for the study and were not aged any further. The paper samples used were purified cotton linter cellulose $\left(40 \mathrm{~g} / \mathrm{m}^{2}\right)$, paper sheets made from mechanical softwood pulp $\left(40 \mathrm{~g} / \mathrm{m}^{2}\right)$ with a $\mathrm{SR}^{\circ}$ of 40 in a Jokro (Rakta paper mill- Alexandria) (Hassan and Mohamed 2017), and a historical paper sample from the manuscript of "Tafsir Al Khazen", which is a book completely made of paper. The historical paper sample was received by the venerable Prince Louaa Ayoub, formerly Dafter Dar of Egypt, Mohamed Abu El Dahab in 1779 AD. The paper sheets were prepared according to the previous works (Hassan 2016; Hassan and Mohamed 2017; Hassan and Mansour 2018). All the paper samples were treated with the highest MICs values reported from the antifungal activity test. To study the effect of oil on paper, the samples were placed in Petri dishes contains cotton saturated with these oils, without contact between the oil and the paper, while the process was carried out through the sublimation of the oil (Massoud et al. 2012). Therefore, there is not impregnation with the oils. Furthermore, text-free samples were used.

\section{TGA methodology}

Thermogravimetric analysis was carried out with a Shimadzu TGA-50 device (Kyoto, Japan) at a temperature range of $22{ }^{\circ} \mathrm{C}$ to $760{ }^{\circ} \mathrm{C}$ in a static nitrogen atmosphere with a heating rate of $10{ }^{\circ} \mathrm{C} / \mathrm{min}$. The temperature ranges of the specimens in this study were evaluated via differential mass loss curves.

\section{Measuring the Color Change}

The color change parameters $L, a$, and $b$ were measured with a HunterLab Labscan 600 spectrocolorimeter (version 3.0; Hunter Associates Laboratory Inc., Reston, VA), where $L$ refers to the black-to-white color, $a$ refers to the green-to-red color, and $b$ refers to the blue-to-yellow color. The total color change of all oil treated paper types was expressed as $\Delta \mathrm{E}$, according to $\mathrm{Eq}, 2$,

$$
\Delta E=\sqrt{(\Delta L)^{2}+(\Delta a)^{2}+(\Delta b)^{2}}
$$

where $(\Delta L)^{2},(\Delta a)^{2}$, and $(\Delta b)^{2}$ are the differences between the values of the color indices before and after oil treatment (Ali et al. 2018; Salem et al. 2020c; Salim et al. 2020).

\section{Statistical Analysis}

The fungi inhibition percentages were statistically analyzed using ANOVA in a completely randomized design with two factors (oil source and oil concentration) using Statistical Analysis System software (version 8.2, SAS, Cary, NC), and compared with the values of the control. The means were compared with a least significant difference (LSD) test at a significance level of a $p$-value less than 0.05 . 


\section{RESULTS AND DISCUSSION}

\section{Chemical Composition and the Antifungal Activity of the Oils}

The chemical compounds of the essential oil (EO) from Citrus aurantiifolia leaves are shown in Table 1 . The primary compounds in the EO were limonene (22.96\%), geranyl acetal $(13.53 \%)$, geraniol acetate $(13.33 \%), \gamma$-dodecalactone $(7.51 \%)$, caryophyllene oxide (7.4\%), $\beta$-caryophyllene (7.36\%), spathulenol (4.95\%), neryl acetal (4.38\%), citronellal $(3.13 \%), \beta$-citral $(2.52 \%)$, and $(E)$-citral $(2.10 \%)$.

Table 1. Phytochemicals of the Essential Oil from Citrus aurantiifolia (leaves) Analysed via GC-MS

\begin{tabular}{|c|c|c|c|}
\hline Compound & Percentage in the Oil (\%) & $\mathrm{SI}^{1}$ & $\mathrm{RSI}^{2}$ \\
\hline D-Limonene & 22.96 & 932 & 932 \\
\hline trans- $\beta$-Ocimene & 0.57 & 828 & 853 \\
\hline Linalool & 0.76 & 939 & 951 \\
\hline Citronellal & 3.13 & 949 & 951 \\
\hline Citronellol & 0.41 & 911 & 924 \\
\hline Nerol (cis-Geraniol) & 0.61 & 891 & 906 \\
\hline Geraniol & 0.54 & 932 & 934 \\
\hline$\beta$-Citral & 2.52 & 903 & 905 \\
\hline $\mathrm{Y}$-Dodecalactone & 7.51 & 864 & 880 \\
\hline$(E)$-Citral & 2.10 & 916 & 964 \\
\hline Geranyl acetal & 13.53 & 800 & 905 \\
\hline Citronellyl formate & 0.85 & 865 & 903 \\
\hline Neryl acetal & 4.38 & 939 & 945 \\
\hline Geraniol acetate & 13.33 & 967 & 973 \\
\hline Linalyl acetate & 0.36 & 831 & 836 \\
\hline$\beta$-Caryophyllene & 7.36 & 938 & 940 \\
\hline$\alpha$-Caryophyllene & 0.61 & 901 & 921 \\
\hline$\alpha$-Farnesene & 0.77 & 869 & 904 \\
\hline$\beta$-Bisabolene & 0.71 & 881 & 909 \\
\hline$y$-Elemene & 0.48 & 833 & 887 \\
\hline Caryophyllene oxide & 7.4 & 921 & 928 \\
\hline Spathulenol & 4.95 & 852 & 884 \\
\hline 2-Methylene- $5 \alpha$-cholestan-3 $\beta$-ol & 1.19 & 820 & 842 \\
\hline Arachidonic acid methyl ester & 0.36 & 802 & 832 \\
\hline Oleic acid & 0.23 & 794 & 807 \\
\hline 1-Heptatriacotanol & 0.18 & 788 & 826 \\
\hline Methyl hexadecadienoate & 1.19 & 774 & 805 \\
\hline
\end{tabular}

Table 2 shows the chemical composition of the $n$-hexane oil (fixed oil) from Citrus reticulata peels as analyzed via gas chromatography-mass spectrometry (GC/MS). The primary compounds were methyl-13-cyclopentyltridecanoate (16.74\%), $D$-limonene $(16.06 \%)$, diethyl phthalate $(13.37 \%)$, oleic acid $(8.02 \%)$, methyl (16E)-16-octadecenoate (5.68\%), 14-pentadecynoic acid methyl ester (4.39\%), 1,3-diolein (4.33\%), and cis-7hexadecenoic acid methyl ester (4.22\%). Table 3 presents the chemical constituents of linseed fixed oil; the primary compounds were linoleic acid (27.36\%), oleic acid (19.01\%), palmitic acid (18.28\%), and methyl hexadecadienoate (16.26\%). 
Table 2. Phytochemicals of the Fixed Oil from Citrus reticulata Peels Extracted Using $n$-Hexane

\begin{tabular}{|c|c|c|c|}
\hline Compound & Percentage in the Oil (\%) & $\mathrm{Sl}^{1}$ & $\mathrm{RSI}^{2}$ \\
\hline D-Limonene & 16.06 & 906 & 917 \\
\hline Methyl dihydromalvalate & 1.00 & 797 & 840 \\
\hline 14-Pentadecynoic acid methyl ester & 4.39 & 819 & 819 \\
\hline cis-7-Hexadecenoic acid methyl ester & 4.22 & 779 & 790 \\
\hline 2-Methylene- $5 \alpha$-cholestan-3 $\beta$-ol & 1.20 & 813 & 836 \\
\hline Diethyl phthalate & 13.37 & 714 & 848 \\
\hline Methyl-13-cyclopentyltridecanoate & 16.74 & 777 & 778 \\
\hline Methyl hexadecadienoate & 2.02 & 819 & 829 \\
\hline cis-9,10-Epoxy-octadecanoic acid & 2.33 & 808 & 818 \\
\hline Oleic acid & 8.02 & 823 & 831 \\
\hline Ethyl iso-allocholate & 0.88 & 804 & 806 \\
\hline Methyl 14-Methylpentadecanoate & 14.02 & 850 & 852 \\
\hline 1,3-Diolein & 4.33 & 812 & 819 \\
\hline Methyl (16E)-16-octadecenoate & 5.68 & 838 & 863 \\
\hline
\end{tabular}

Table 3. Phytochemicals of the Fixed Oil from Flaxseed (Linum usitatissimum) Analysed via GC-MS

\begin{tabular}{|c|c|c|c|}
\hline Compound & Percentage in the Oil (\%) & $\mathrm{SI}^{1}$ & $\mathrm{RSI}^{2}$ \\
\hline Linoleoyl chloride & 5.32 & 752 & 783 \\
\hline$\alpha$-Linoleic acid & 27.36 & 798 & 815 \\
\hline 7-Methyl-Z-tetradecen-1-ol acetate & 6.91 & 763 & 783 \\
\hline Palmitic acid & 18.28 & 788 & 797 \\
\hline Methyl hexadecadienoate & 16.26 & 789 & 794 \\
\hline Stearic acid & 3.54 & 794 & 808 \\
\hline Oleic acid & 19.01 & 829 & 830 \\
\hline Note: SI = Standard Index; and RSI = Reverse Standard index & \multicolumn{1}{l}{} \\
\hline
\end{tabular}

As indicated in Table 4, the oils from Linum usitatissimum, Citrus reticulata, and C. aurantifolia showed different antifungal activity levels against the studied fungi (Aspergillus flavus and Penicillium chrysogenum). Generally, the inhibitory effect of the oils increased in proportion with an increase in concentration, and maximum inhibition was reached at the final concentration of $2000 \mu \mathrm{L} / \mathrm{mL}$. Table 4 presents the growth inhibition (GI) percentage of the A. flavus and P. chrysogenum fungal mycelial, and how the GI values were affected by the three oils. At all the studied concentrations, the GI\% significantly reached $100 \%$ as the essential oil from $C$. aurantifolia leaves was tested as antifungal agent against the growth of $A$. flavus, while it reached $100 \%$ as seed oil from $L$. usitatissimum was tested at the concentration of $2000 \mu \mathrm{L} / \mathrm{mL}$ in comparison with the control ( $p$-value less than 0.05 via ANOVA). While $C$. reticulata peel EO yielded GI\% values of $57.41 \%$ in terms of $A$. flavus growth, $C$. aurantifolia oil yielded the highest GI\% values $(100 \%)$ with significant antifungal activity ( $p$-value less than 0.05 ) against $P$. chrysogenum at concentrations of $125 \mu \mathrm{L} / \mathrm{mL}, 250 \mu \mathrm{L} / \mathrm{mL}, 500 \mu \mathrm{L} / \mathrm{mL}, 1000 \mu \mathrm{L} / \mathrm{mL}$, and $2000 \mu \mathrm{L} / \mathrm{mL}$ and reached a GI value of $81.48 \%$ at $62 \mu \mathrm{L} / \mathrm{mL}$, when compared to the control treatment. Citrus reticulata peel oil yielded significant ( $p$-value less than 0.05) GI values, with $100 \%$ of the fungal growth inhibited at the concentrations of $2000 \mu \mathrm{L} / \mathrm{mL}$ and 1000 $\mu \mathrm{L} / \mathrm{mL}$ against $P$. chrysogenum. In addition, L. usitatissimum seed oil applied at 2000 $\mu \mathrm{L} / \mathrm{mL}$ yielded a GI value of $100 \%$, when compared to the control treatment. 
Table 4. Antifungal Activity of the Tested Oils Against Aspergillus flavus and Penicillium chrysogenum

\begin{tabular}{|c|c|c|c|}
\hline Oil & Conc $(\mu \mathrm{L} / \mathrm{mL})$ & $\begin{array}{l}\text { Aspergillus } \\
\text { flavus }\end{array}$ & $\begin{array}{c}\text { Penicillium } \\
\text { chrysogenum }\end{array}$ \\
\hline \multirow{7}{*}{ Citrus reticulata (peels) } & $\begin{array}{c}0 \text { (10\% DMSO, } \\
\text { control) }\end{array}$ & 0.00 & 0.00 \\
\hline & 62 & $16.2 \pm 0.37$ & $38.5 \pm 0.37$ \\
\hline & 125 & $20.3 \pm 0.37$ & $71.4 \pm 0.37$ \\
\hline & 250 & $27 \pm 0.37$ & $75.9 \pm 0.37$ \\
\hline & 500 & $41.8 \pm 0.37$ & $80.3 \pm 0.37$ \\
\hline & 1000 & $57.4 \pm 0.37$ & 100 \\
\hline & 2000 & 100 & 100 \\
\hline \multirow{7}{*}{ Citrus aurantifolia (leaves) } & $\begin{array}{c}0 \text { (10\% DMSO, } \\
\text { control) }\end{array}$ & 0.00 & 0.00 \\
\hline & 62 & 100 & $81.4 \pm 0.37$ \\
\hline & 125 & 100 & 100 \\
\hline & 250 & 100 & 100 \\
\hline & 500 & 100 & 100 \\
\hline & 1000 & 100 & 100 \\
\hline & 2000 & 100 & 100 \\
\hline \multirow{7}{*}{ Linum usitatissimum (seed) } & $\begin{array}{c}0 \text { (10\% DMSO, } \\
\text { control) }\end{array}$ & 0.00 & 0.00 \\
\hline & 62 & $4.8 \pm 0.37$ & $72.9 \pm 0.37$ \\
\hline & 125 & $17 \pm 0.37$ & $74.8 \pm 0.37$ \\
\hline & 250 & $36.2 \pm 0.37$ & $80.3 \pm 0.37$ \\
\hline & 500 & $42.9 \pm 0.37$ & $82.5 \pm 0.37$ \\
\hline & 1000 & $47 \pm 0.37$ & $84.8 \pm 0.37$ \\
\hline & 2000 & 100 & 100 \\
\hline$p$-value & & $<0.0001$ & $<0.0001$ \\
\hline
\end{tabular}

Table 5 shows the MIC results of the studied oils, where the lowest MIC values were less than $2 \mu \mathrm{L} / \mathrm{mL}$. This level of $C$. aurantifolia leaf essential oil was applied to inhibit the growth of A. flavus and $P$. chrysogenum, respectively. Therefore, the highest MIC values were $6 \mu \mathrm{L} / \mathrm{mL}, 2 \mu \mathrm{L} / \mathrm{mL}$, and $32 \mu \mathrm{L} / \mathrm{mL}$ for $C$. reticulata (peels), C. aurantifolia (leaves), and Linum usitatissimum (seed), respectively. These concentrations were used to treat the paper made with mechanical softwood pulp, cotton paper, and historical paper.

Table 5. Minimum Inhibitory Concentrations (MICs) of the Oil Treatments

\begin{tabular}{|c|c|c|}
\hline \multirow{2}{*}{ Source of Oil } & \multicolumn{2}{|c|}{$\mathrm{MIC}(\mu \mathrm{L} / \mathrm{mL})$} \\
\cline { 2 - 3 } & Aspergillus flavus & Penicillium chrysogenum \\
\hline Citrus reticulata (peels) & 4 & 6 \\
\hline Citrus aurantifolia (leaves) & $<2$ & 2 \\
\hline Linum usitatissimum (seed) & 32 & 16 \\
\hline
\end{tabular}

In a study by Razzaghi-Abyaneh (2018), D-limonene was found to make up $22.96 \%$ of the compounds in the essential oil of $C$. aurantifolia leaves, but it reached $85.5 \%$ in the plants grown in Iran. In a study by Al-Aamri et al. (2018), D-limonene (63.35\%) formed the major constituent of $C$. aurantifolia essential oil; however, other compounds, including 3,7-dimethyl-2,6-octadien-1-ol, geraniol, $E$-citral, $Z$-citral, and $\beta$-ocimene (7.07\%, 6.23\%, $4.35 \%, 3.29 \%$, and $2.25 \%$, respectively), were found. In a study by Ibrahim et al. (2019), D-limonene (57.84\%) was the primary compound in C. aurantifolia leaf essential oil, with 
notable compounds, including neral, linalool, sulcatone, and isogeraniol $(7.81 \%, 4.75 \%$, $3.48 \%$, and $3.48 \%$, respectively), were identified. A study by Lemes et al. (2018) found limonene, linalool, citronellal, and citronellol as the main constituents $(77.5 \%, 20.1 \%$, $14.5 \%$, and $14.2 \%$, respectively), in the essential oils from C. aurantifolia leaves and fruit peels, which showed promising activity against Streptococcus mutans and Lactobacillus casei.

Samples of $C$. aurantifolia from Italy contained limonene, $\beta$-myrcene, citral, $\gamma$ terpinene, $\beta$-pinene, and $\beta$-bisabolene as the primary compounds (Tundis et al. 2012; Spadaro et al. 2012). In addition, limonene and $\beta$-pinene were the major components in the essential oil extracted from C. aurantifolia collected in South Korea (Hong et al. 2017). Citrus aurantifolia leaf essential oil showed an inhibition value against A. parasiticus (47.8\%) and therefore was considered to possess the ability to suppress this fungus (Rammanee and Hongpattarakere 2011). According to a study by Abo Elgat et al. (2020b), Citrus sinensis peel essential oil showed potential antifungal activity against $A$. flavus with a GI of $86.66 \%$ when applied at a concentration of $50 \mu \mathrm{L} / \mathrm{mL}$. Dongmo et al. (2009) observed that $C$. aurantifolia essential oil had a fungicidal inhibiting action on the radial growth of Phaeoramularia angolensis.

Limonene $(46.7 \%)$, followed by geranial, neral, geranyl acetate, geraniol, $\beta$ caryophyllene, nerol, neryl acetate $(19 \%, 14.5 \%, 3.9 \%, 3.5 \%, 2.3 \%, 2.6 \%$, and $1.1 \%$, respectively) were found in the oil extracted from $C$. reticulata Blanco grown in India (Chutia et al. 2009), which possessed good antifungal activity against plant pathogenic fungi Alternaria alternata, Rhizoctonia solani, Curvularia lunata, Fusarium oxysporum, and Helminthosporium oryzae. Citrus reticulata essential oil at a concentration of $0.94 \%$ showed a $100 \%$ reduction of the growth of A. flavus and P. chrysogenum (Viuda-Martos et al. 2008).

The antifungal activity of the extracted oils is associated with the phytochemical components, e.g., monoterpenes (Matasyoh et al. 2007), which are able to diffuse into cell membrane structures and damage them. Sokovic and Griensven (2006) observed that limonene and $\alpha$-pinene possessed antifungal activity (a MIC of $4.0 \mu \mathrm{L} / \mathrm{mL}$ to $9.0 \mu \mathrm{L} / \mathrm{mL}$ ) against Verticillium fungicola and Trichoderma harzianum, which are found at different amount in different plant essential oils (limonene and $\alpha$-pinene). The essential oils and their related substances made the cell membrane of the fungus permeable, causing leakage (Piper et al. 2001).

Fatty acids, i.e., linoleic, oleic, and palmitic, are the primary identified compounds in linseed essential oil. It was reported by Coşkuner and Karababa (2007) that the primary oil constituents were linoleic acid, oleic acid, and $\alpha$-linolenic acid, with values ranging from $8 \%$ to $29 \%, 12 \%$ to $30 \%$, and $35 \%$ to $67 \%$, respectively. In addition, $\alpha$-linolenic acid, linoleic acid, palmitic acid, oleic acid, and stearic acid were found in the ranges of $39.9 \%$ to $60.42 \%, 12.25 \%$ to $17.44 \%, 4.9 \%$ to $8 \%, 13.44 \%$ to $19.39 \%$, and $2.24 \%$ to $4.59 \%$, respectively, in a study by Goyal et al. (2014); additional studies found these compounds comprised $53 \%, 17 \%, 5 \%, 19 \%$, and $3 \%$ of the primary compounds, respectively (Simopoulos 2002; Bernacchia et al. 2014). Linseed oil from a Romanian plant contained high levels of linolenic acid $(53.21 \%)$ followed by oleic acid, linoleic acid, palmitic acid, and stearic acid $(18.51 \%, 17.25 \%, 6.58 \%$, and 4.43\%, respectively) (Popa et al. 2012). Fatty acids $\alpha$-linolenic (51.37\%), oleic (20.59\%), linoleic (15.8\%), palmitic $(5.86 \%)$, and stearic $(5.57 \%)$ were reported as the primary compounds in the linseed oil analyzed in a study by Danish and Nizami (2019).

For linseed oil, the biological activity action of fatty acids is attributed to its 
unsaturated long-chain fatty acids, i.e., linoleic, linolenic, and oleic (Xu et al. 2008; Mueller et al. 2010; Chandrasekaran et al. 2011), while its saturated long-chain fatty acids, i.e., stearic and palmitic, are less active (Seidel and Taylor 2004). The potential antifungal activity of linseed oil against Aspergillus ochraceus and A. flavus could be due to its rich $\alpha$-linolenic acid and linoleic acid content (Abdelillah et al. 2013). Petroleum ether extract showed good antifungal activity against Candida albicans (Guilloux et al. 2009; Kaithwas et al. 2011), Flaxseed flour showed promising fungistatic activity against Fusarium graminearum, A. flavus, and Penicillium chrysogenum (Xu et al. 2008), while defatted flaxseed powder exhibited bioactivity against A. flavus and A. niger (Barbary et al. 2010). Linseed powder at a $6 \%$ concentration completely inhibited the development of A. flavus (Xu et al. 2008).

\section{Thermogravimetric Properties of the Treated Paper Samples}

Thermogravimetric analysis (TGA) is a simple and accurate method for studying the decomposition pattern and thermal stability of paper after treatment. Figures 1, 2, and 3 show the primary thermo-grams and derivato-grams for the reference paper sources, softwood pulp, cotton, and historical paper, respectively, as well as the samples treated with oil.

The references paper samples (wood-based, cotton, and historical paper) had an initial weight loss of $3.6 \%, 3.3 \%$, and $2.86 \%$, respectively, at approximately $105{ }^{\circ} \mathrm{C}$, which is primarily due to the evaporation of any absorbed moisture (Madera-Santana et al. 2002; Hassan 2020). The primary decomposition proceeds in one step (Nasr and Ismail 2010) for each type of paper, i.e., in the cotton sample the weight loss of $3.3 \%$ occurs at a decomposition temperature $\left(T_{\mathrm{d}}\right)$ of $107^{\circ} \mathrm{C}$ and the weight loss of $3.6 \%$ for the wood-based sample occurred at a $T_{\mathrm{d}}$ of $105.6{ }^{\circ} \mathrm{C}$. Furthermore, the authors were able to detect similar behavior between the untreated samples (Table 6).

The data in Table 6 show the difference in the results of the modern paper samples and the historical sample; the historical sample started the initial weight loss at high temperatures than the modern samples (the $T_{\mathrm{d}}$ of the historical sample was approximately $201{ }^{\circ} \mathrm{C}$ ). Thermal gravimetric analysis allowed a conclusion to be drawn that the thermo oxidation destruction of historical paper, before and after treatment, was a multistage process, which involved at least three stages.

The maximum rate of the first stage of thermal oxidation can be determined by the weight loss rate, which is considered a major determinate of the degree of paper destruction. The data from Table 6 shows that the historical paper samples with the highest degree of destruction exhibited the highest rate of destruction during the first stage. For the historical paper samples, the lowest mass loss that occurs during stage II of the paper destruction process is related to the partial splitting of cellulose macromolecules, and therefore, increases the heterogeneousness of its structures (Kamel et al. 2004).

To examine the mass loss brought about by high temperatures, $\mathrm{d} M / \mathrm{d} T$ curves (calculated by deriving weight loss $v s$. temperature data) are given for references and treated paper with oils, as shown in Figs. 1 through 3. Degradation of untreated paper started at a temperature lower than $105^{\circ} \mathrm{C}$ and degraded with much higher speed than treated samples. Initial degradation temperature of treated samples were much lower than references ones, and also the speed was much slower. In the heat versus weight loss curve, the mass loss peaks of untreated and treated took place at different temperatures. For woodbased paper, the mass loss peak occurred at a much lower temperature than cotton samples. Treating paper by oils made paper more thermally stable and increased the ash content, as 
shown in Figs. 1 and 2. Although the improvement was (as it was not detected very clearly), a small improvement in thermal stability was considered important. It should be noted that the samples treated with Linum usitatissimum gave the highest thermal stability, especially with cotton samples. In accordance with the literature (Le Moigne 2008; Youssef $e$ al. 2012), there was no degradation before $50{ }^{\circ} \mathrm{C}$. Above this temperature, thermal stability gradually decreased, and decomposition of the fibers occurred in treated paper with two different steps: one peak below $40{ }^{\circ} \mathrm{C}$, and another one at $105{ }^{\circ} \mathrm{C}$. The first peak was assigned to the decomposition of oils, and it shifted to higher temperature than in untreated samples. The second inflection with the sharp peak was at the same $T_{\mathrm{d}}$ of original paper. The data show the effect of treatment on total initial weight loss; it is obvious that the treatment decreased total initial weight loss, especially for the samples treated with $C$. reticulata oil. Treated cotton with Linum usitatissimum and wood-based paper treated with Citrus reticulata had the highest and lowest stability, respectively.

However, there was a change of the destruction mechanism from hydrolytic to hemolytic, which might be due to stearic acid (in the chemical structure of the oils), which it is believed to enhance the hydrophobicity of the negative active material. It also reduces the extension of oxidation in the open atmosphere (Wang et al. 2007). Moreover, the loss of free water in paper results in a loss of flexibility, while the loss of bound water results in its deterioration, due to changes that occur in its chemical structure and physical properties (Hassan 2015).

Paper samples treated with linseed oil showed the highest mass loss values, but it should be taken into consideration that the end temperature was dramatically increased in comparison to the standard sample, which confirms the impact of linseed oil on the thermal characteristics of treated paper at high temperatures. The authors were able to identify two mechanisms of oxidation in linseed oil: (i) the poor oxidative stability of linseed oil at low temperatures can attributed to a high $\alpha$-linolenic acid content (Rudnik et al. 2001); and (ii) the good oxidative stability of linseed oil at high temperatures can increase the rate of protection from oxidation at high temperatures, which was consistent with various studies. Khattab et al. (1999) found that as the linseed oil concentration in the cotton paper sample increases, the apparent activation energies of pyrolysis and oxidation decrease, due to the hypothesized formation of free radicals via the oxidation of linseed oil, which then catalyze the pyrolysis reactions of cotton. Linseed oil oxidation, which incorporates cross-linking reactions, involves oxygen consumption, and thus induces increased sample mass. Therefore, the mass reading of a TGA instrument corresponds to a combined effect of mass gaining reactions, i.e., oxygen consumption, and mass losing reactions, i.e., emission of carbon oxides and water. For this reason, gravimetric techniques alone are insufficient to investigate the spontaneous ignition of linseed oil impregnated into cellulose materials.

The results show the effectiveness of the oils at improving the thermal stability properties of the treated paper at different temperatures, especially C. aurantifolia oil, which improved the thermal properties of both cotton paper and wood-based paper dramatically, as the end temperature of the primary decomposition temperature was higher than the decomposition temperature of the standard sample. However, it must be noted that the improvement mechanism was linked to a closed link with the type of paper pulp, i.e., C. aurantifolia oil yielded the best results with cotton pulp, while L. usitatissimum oil yielded promising results with softwood mechanical pulp-based and historical papers. 

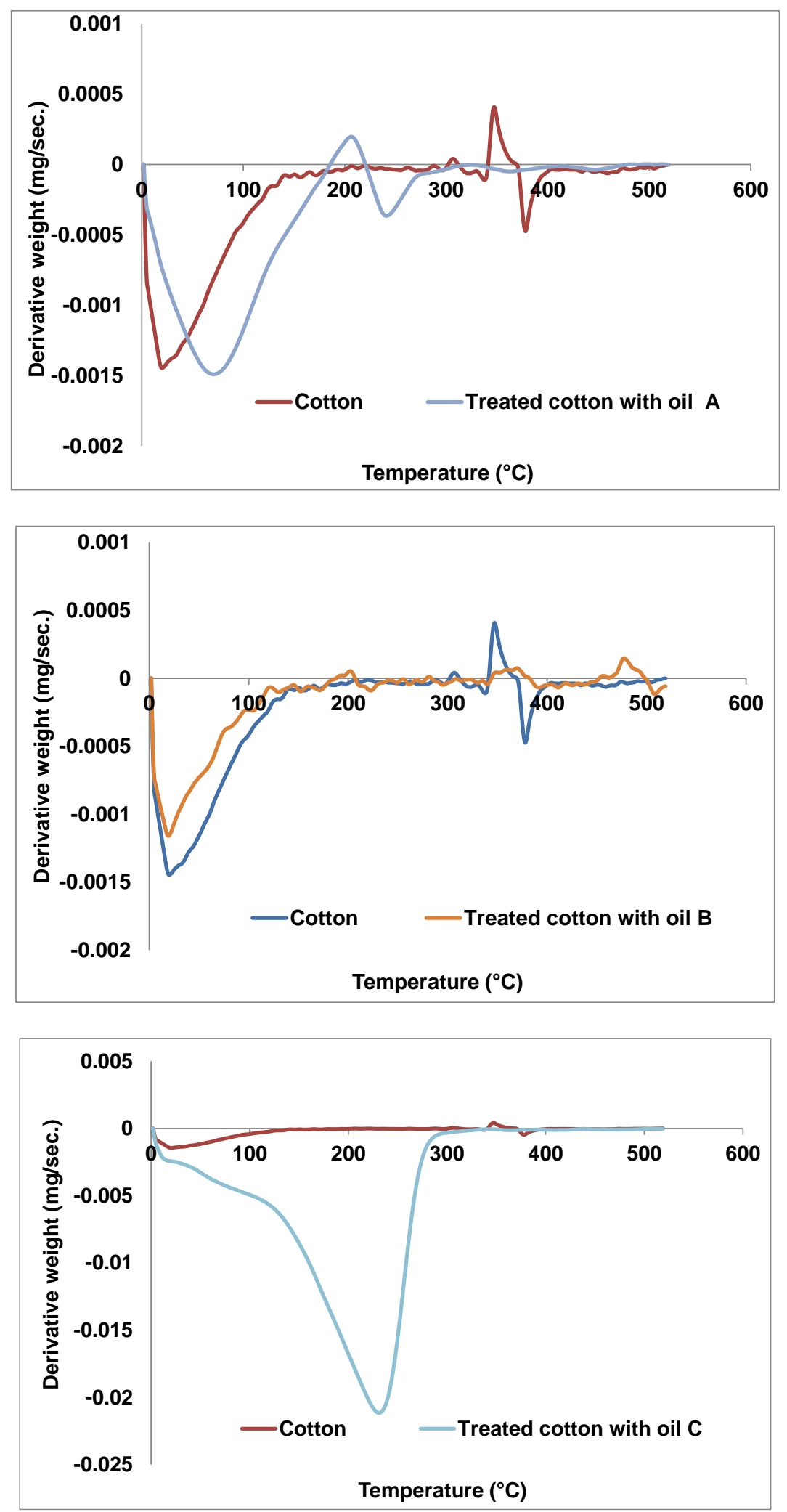

Fig. 1. Thermogravimetric analysis (TGA) for the weight change $(\mathrm{mg} / \mathrm{sec}$.) for the cotton paper samples before and after treatment with the three oils (A) Citrus reticulata; (B) Citrus aurantifolia; (C) Linum usitatissimum 

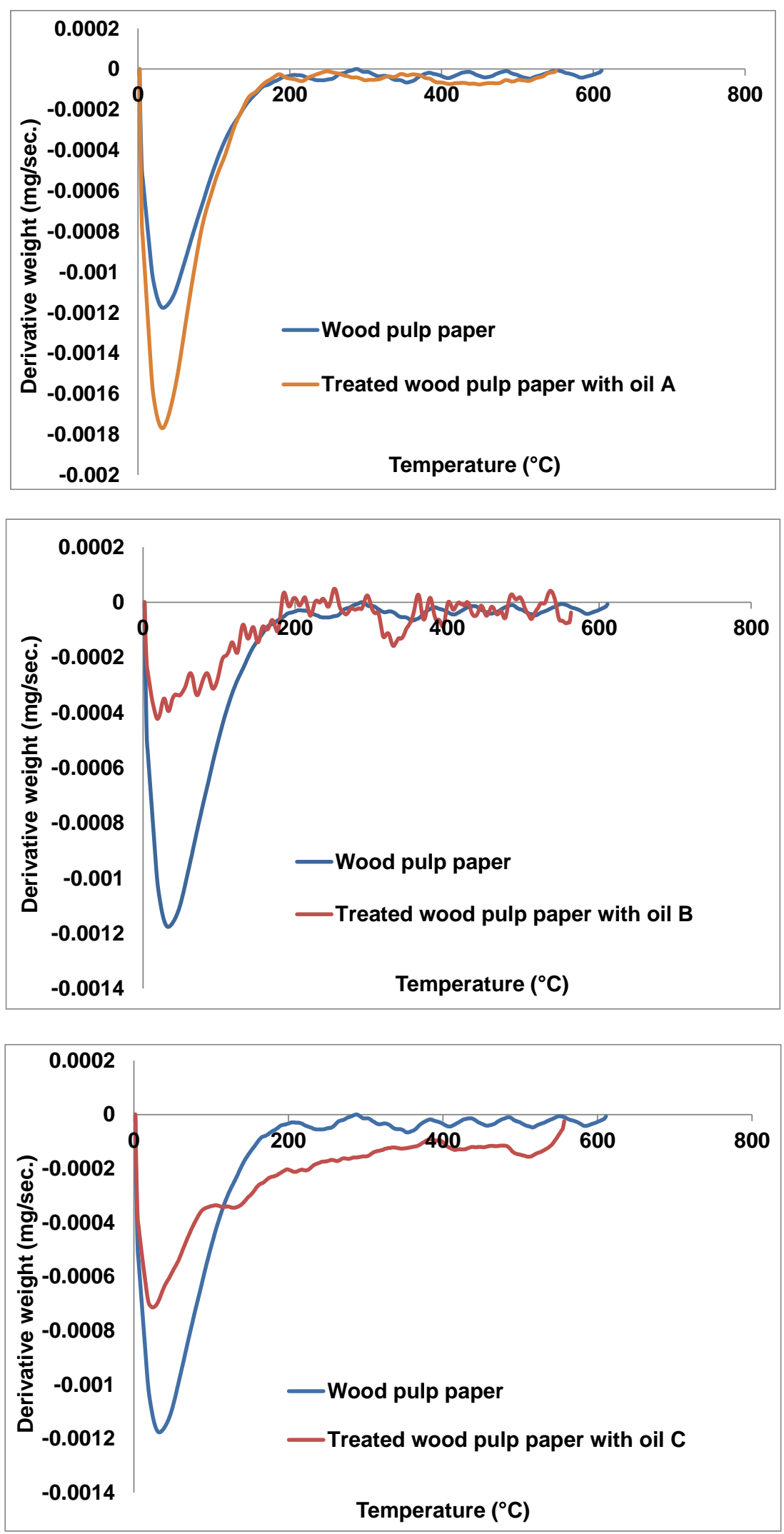

Fig. 2. Thermogravimetric analysis (TGA) for the weight change $(\mathrm{mg} / \mathrm{sec}$.) for the wood-based paper samples before and after treatment with the three oils A) Citrus reticulata; (B) Citrus aurantifolia; (C) Linum usitatissimum 

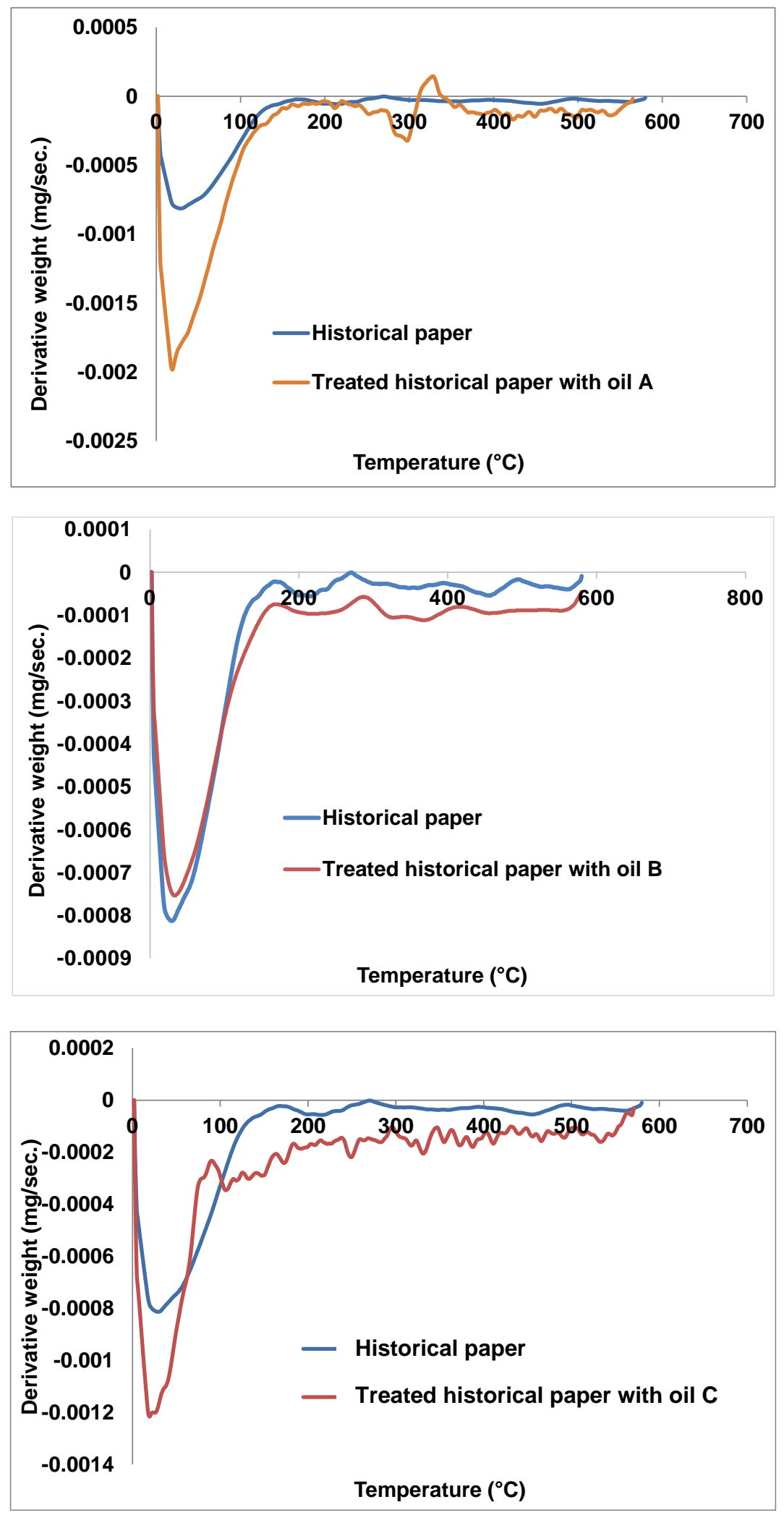

Fig. 3. Thermogravimetric analysis (TGA) for the weight change $(\mathrm{mg} / \mathrm{sec}$.) for the historical paper samples before and after treatment with the three oils. A) Citrus reticulata; (B) Citrus aurantifolia; (C) Linum usitatissimum 
Table 6. Parameters of the Thermo-Oxidation Destruction for Paper Samples Before and After Oil Treatment

\begin{tabular}{|c|c|c|c|c|}
\hline Source of Paper & Treated with Tested Oil & Start $\left({ }^{\circ} \mathrm{C}\right)$ & End $\left({ }^{\circ} \mathrm{C}\right)$ & Weight Loss $(\mathrm{mg})$ \\
\hline \multirow{3}{*}{ Cotton } & Control & 37.94 & 107 & $-0.102(3.3 \%)$ \\
\cline { 2 - 5 } & Citrus reticulata & 39.45 & 95.1 & $-0.06(2.9 \%)$ \\
\cline { 2 - 5 } & Citrus aurantifolia & 18.61 & 201.8 & $-0.17(4.22 \%)$ \\
\cline { 2 - 5 } & Linum usitatissimum & 35.7 & 148.8 & $-2.45(6.7 \%)$ \\
\hline \multirow{3}{*}{ Wood-based } & Control & 43.88 & 105.6 & $-1.01(3.6 \%)$ \\
\cline { 2 - 5 } & Citrus reticulata & 36.3 & 104.6 & $-0.13(3.6 \%)$ \\
\cline { 2 - 5 } & Citrus aurantifolia & 38.5 & 107.9 & $-0.01(2.0 \%)$ \\
\cline { 2 - 5 } & Linum usitatissimum & 37.55 & 201.3 & $-0.13(4.4 \%)$ \\
\hline \multirow{3}{*}{ Historical } & Control & 44.25 & 201.7 & $-0.09(2.86 \%)$ \\
\cline { 2 - 5 } & Citrus reticulata & 37.98 & 100.59 & $-0.130(3.16 \%)$ \\
\cline { 2 - 5 } & Citrus aurantifolia & 41.97 & 98.25 & $-0.063(2.03 \%)$ \\
\cline { 2 - 5 } & Linum usitatissimum & 36.54 & 201.06 & $-0.148(4.9 \%)$ \\
\hline
\end{tabular}

\section{Total Color Differences $(\Delta E)$}

The results of the total color change values $(\Delta E)$ for the paper samples before and after treatment with the tested three oils are shown in Table 7 . The results confirmed that after the oil treatments, the $\Delta E$ values of the treated wood-based paper samples decreased significantly; the $\Delta E$ of the wood-based paper sample treated with L. usitatissimum oil was 2.11, while the $\Delta E$ was even higher when treated with $C$. aurantifolia oil $(\Delta E 9.33)$ and $C$. reticulata $(6.65 \Delta E)$.

Table 7. Total Color Differences of Paper Samples Before and After Treatment with Oils

\begin{tabular}{|l|l|l|l|l|l|}
\hline Source of samples & Oil source & $L$ & $a$ & $b$ & $\Delta E$ \\
\hline \multirow{3}{*}{$\begin{array}{l}\text { Paper from softwood } \\
\text { pulp }\end{array}$} & Blank & 91.77 & 0.64 & 8.84 & \\
\cline { 2 - 6 } & C. reticulata & 87.27 & 1.41 & 13.68 & 6.65 \\
\cline { 2 - 6 } & C. aurantifolia & 86.31 & 2.69 & 16.13 & 9.33 \\
\cline { 2 - 6 } & L. usitatissimum & 90.92 & 0.78 & 7.43 & 2.11 \\
\hline \multirow{5}{*}{ Cotton paper } & Blank & 91.10 & 0.69 & 9.03 & \\
\cline { 2 - 6 } & C. reticulata & 85.47 & 3.08 & 8.95 & 6.11 \\
\cline { 2 - 6 } & C. aurantifolia & 89.97 & 0.50 & 10.84 & 2.14 \\
\cline { 2 - 6 } & L. usitatissimum & 84.64 & 1.79 & 10.93 & 6.82 \\
\hline Historical paper & Blank & 86.72 & 1.79 & 10.30 & \\
\cline { 2 - 6 } & C. reticulata & 90.49 & 1.48 & 3.74 & 7.57 \\
\cline { 2 - 6 } & C. aurantifolia & 80.45 & 2.42 & 11.08 & 6.34 \\
\cline { 2 - 6 } & L. usitatissimum & 84.94 & 1.96 & 9.10 & 2.15 \\
\hline
\end{tabular}

For treated the cotton paper samples, significant color change was found in the samples treated with $C$. aurantifolia and $L$. usitatissimum oils, with $\Delta E$ values of 6.11 and 6.82, respectively, however the $\Delta E$ decreased to 2.14 when treated with $C$. aurantifolia oil. The treated historical paper samples yielded $\Delta E$ values of $7.57,6.34$, and 2.15 when the paper was treated with the oils from $C$. aurantifolia, C. aurantifolia and L. usitatissimum, respectively. These results confirmed that the oils from L. usitatissimum, C. aurantifolia and L. usitatissimum played a vital role in reducing the color change values in wood-based paper, cotton paper, and historical paper, respectively. Table 6 shows that L. usitatissimum oil provided the best color change protection, as yielded the lowest $\Delta E$ values for the treated samples, which were classified as not noticeable to the naked eye, since their value was less than 5 (Hassan 2019, 2020b). 


\section{CONCLUSIONS}

1. The effect of using three natural oils as antifungal agents, as well as their effects on the thermogravimetric, chromatic behaviors of a historical paper sample, and paper sheets made from softwood mechanical pulp and cotton were studied. The results indicated that the three oils assayed possessed antifungal properties against Aspergillus flavus and Penicillium chrysogenum, ranked in the following order: C. aurantifolia was greater than $C$. reticulata, which was greater than L. usitatissimum. These three essential oils could be used to control fungal infestations on various types of paper.

2. The thermogravimetric and chromatic alternations analyses demonstrated a positive effect of $C$. aurantifolia $\mathrm{EO}$ and color change protection to cotton pulp, while linseeds oil showed positive effects with wood pulp-based and historical papers.

3. The positive effect of the oils on the thermal properties of the papers provided a significant increase in the initial decomposition temperatures after treatment, but this improvement was linked to the type of paper.

\section{ACKNOWLEDGMENTS}

The authors would like to extend their sincere appreciation to the Deanship of Scientific Research at the King Saud University for funding this work through research group No. RG 1435-011.

\section{REFERENCES CITED}

Abbassy, M. M. S., Salem, M. Z. M., Rashad, N. M., Afify, S. M., and Salem, A. Z. M. (2020). "Nutritive and biocidal properties of agroforestry trees of Moringa oleifera Lam., Cassia fistula L., and Ceratonia siliqua L. as non-conventional edible vegetable oils," Agroforestry System 94, 1567-1579, DOI: 10.1007/s10457-018-0325-4

Abdelillah, A., Houcine, B., Halima, D., Meriem, C. S., Imane, Z., Eddine, S. D., Abdallah, M., and Daoudi C. S. (2013). "Evaluation of antifungal activity of free fatty acids methyl esters fraction isolated from Algerian Linum usitatissimum L. seeds against toxigenic Aspergillus," Asian Pacific Journal of Tropical Biomedicine 3(6), 443-448. DOI: 10.1016/S2221-1691(13)60094-5

Abdelsalam, N. R., Salem, M. Z. M., Ali, H. M., Mackled, M. I., EL-Hefny, M., Elshikh, M. S., and Hatamleh, A. A. (2019). "Morphological, biochemical, molecular, and oil toxicity properties of Taxodium trees from different locations," Industrial Crops and Products 139, DOI: 10.1016/j.indcrop.2019.111515

Abo Elgat, W. A. A., Kordy, A. M., Böhm, M., Černý, R., Abdel-Megeed, A., and Salem, M. Z. M. (2020b). "Eucalyptus camaldulensis, Citrus aurantium and Citrus sinensis essential oils as antifungal activity against Aspergillus flavus, Aspergillus niger, Aspergillus terreus, and Fusarium culmorum," Processes 8(8), 1-16. DOI: $10.3390 / \mathrm{pr} 8081003$

Abo Elgat, W. A. A., Taha, A. S., Böhm, M., Vejmelková, E., Mohamed, W. S., Fares, Y. G. D., and Salem, M. Z. M. (2020a). "Evaluation of the mechanical, physical, and anti-fungal properties of flax laboratory papersheets with the nanoparticles 
treatment," Materials 13(2), 1-23. DOI: 10.3390/ma13020363

Aibinu, I., Adenipekun, T., Adelowotan, T., Ogunsanya, T., and Odugbemi, T. (2007). "Evaluation of the antimicrobial properties of different parts of Citrus aurantifolia (lime fruit) as used locally," African Journal of Traditional, Complementary and Alternative Medicines 4(2), 185-190.

Al-Aamri, M. S., Al-Abousi, N. M., Al-Jabri, S. S., Alam, T., and Khan, S. A. (2018). "Chemical composition and in-vitro antioxidant and antimicrobial activity of the essential oil of Citrus aurantifolia L. leaves grown in Eastern Oman," Journal of Taibah University Medical Sciences, 13(2), 108-112. DOI:

10.1016/j.jtumed.2017.12.002

Al-Huqail, A. A., Behiry, S. I., Salem, M. Z. M., Ali, H. M., Siddiqui, M. H., and Salem, A. Z. M. (2019). "Antifungal, antibacterial, and antioxidant activities of Acacia saligna (Labill.) H. L. Wendl. flower extract: HPLC analysis of phenolic and flavonoid compounds," Molecules 24(4), 1-14. DOI: 10.3390/molecules24040700

Ali, M. F., Mansour, M. M. A., Badr, N. M., and Salem, M. Z. M. (2018). “A study of biodeterioration and chromatic alterations of painted and gilded mummy cartonnage at the Saqqara museum storeroom, Egypt," Archaeometry 60(4), 845-858. DOI: $10.1111 /$ arcm. 12340

Al-Mathkhury, H. J. F., Al-Dhamin, A. S., and Al-Taie, K. L. (2016). "Antibacterial and antibiofilm activity of flaxseed oil," Iraqi Journal of Science 57(2B), 1086-1095.

Ashmawy, N. A., Al Farraj, D. A., Salem, M. Z. M., Elshikh, M. S., Al-Kufaidy, R., Alshammari, M. K., and Salem, A. Z. M. (2020a). "Potential impacts of Pinus halepensis Miller trees as a source of phytochemical compounds: Antibacterial activity of the cones essential oil and $n$-butanol extract," Agroforestry System 94, 1403-1413, DOI: 10.1007/s10457-018-0324-5

Ashmawy, N. A., Behiry, S. I., Al-Huqail, A. A., Ali, H. M., and Salem, M. Z. M. (2020b). "Bioactivity of selected phenolic acids and hexane extracts from Bougainvilla spectabilis and Citharexylum spinosum on the growth of Pectobacterium carotovorum and Dickeya solani bacteria: An opportunity to save the environment," Processes 8(4), 1-16. DOI: 10.3390/pr8040482

Barbary, O. M., El-Sohaimy, S. A., El-Saadani, M. A., and Zeitoun, A. M. A. (2010). "Antioxidant, antimicrobial and anti-HCV activities of lignan extracted from flaxseed," Research Journal of Agriculture and Biological Sciences 6(3), 247-256.

Bayrak, A., Kiralan, M., Ipek, A., Arslan, N., Cosge, B. and Khawar, K. M. (2010). "Fatty acid compositions of linseed (Linum usitatissimum L.) genotypes of different origin cultivated in Turkey," Biotechnology \& Biotechnological Equipment 24(2), 1836-1842. DOI: 10.2478/V10133-010-0034-2

Behiry, S. I., Nasser, R. A., Abd El-Kareem, M. S. M., Ali, H. M., and Salem, M. Z. M. (2020). "Mass spectroscopic analysis, MNDO quantum chemical studies and antifungal activity of essential and recovered oil constituents of lemon-scented gum against three common molds," Processes 8(3), 1-24. DOI: 10.3390/pr8030275

Bernacchia, R., Preti, R., and Vinci, G. (2014). "Chemical composition and health benefits of flaxseed," Austin Journal of Nutrition and Food Sciences, 2(8), 1-9.

Chandrasekaran, M., Senthilkumar, A., and Venkatesalu, V. (2011). "Antibacterial and antifungal efficacy of fatty acid methyl esters from the leaves of Sesuvium portulacastrum L," European Review for Medical and Pharmacological Sciences 15(7), 775-780.

Chauhan, R., Chester, K., Khan, Y., Tamboli, E. T., and Ahmad, S. (2015). 
"Characterization of Linum usitatissimum L. oil obtained from different extraction technique and in vitro antioxidant potential of supercritical fluid extract." Journal of Pharmacy \& BioAllied Science 7(4), 284-288. DOI: 10.4103/0975-7406.168027

Chutia, M., Bhuyan, P. D., Pathak, M. G., Sarma, T. C., and Boruah, P. (2009). "Antifungal activity and chemical composition of Citrus reticulata Blanco essential oil against phytopathogens from North East India," LWT - Food Science and Technology 42(3), 777-780. DOI: 10.1016/j.lwt.2008.09.015

Clinical and Laboratory Standards Institute (CLSI) (2008). Reference Method for Broth Dilution Antifungal Susceptibility Testing of Filamentous Fungi; Approved StandardSecond Edition (CLSI document M38-A2), Clinical and Laboratory Standards Institute, Wayne, PA.

Coşkuner, Y., and Karababa, E. (2007). "Some physical properties of flaxseed (Linum usitatissimum L.)," Journal of Food Engineering 78(3), 1067-1073. DOI: 10.1016/j.jfoodeng.2005.12.017

da Silva, M., Moraes, A. M. L., Nishikawa, M. M., Gatti, M. J. A., de Alencar, M. A. V., Brandão, L. E., and Nóbrega, A. (2006). "Inactivation of fungi from deteriorated paper materials by radiation," International Biodeterioration \& Biodegradation, 57(3), 163-167. DOI: 10.1016/j.ibiod.2006.02.003

Danish, M., and Nizami, M. (2019). "Complete fatty acid analysis data of flaxseed oil using GC-FID method," Data in Brief 23, 103845. DOI: 10.1016/j.dib.2019.103845

Dongmo, P. M. J., Tatsadjieu, L. N., Sonwa, E. T., Kuate, J., Zollo, P. H. A., and Menut, C. (2009). "Essential oils of Citrus aurantifolia from Cameroon and their antifungal activity against Phaeoramularia angolensis," African Journal of Agricultural Research 4(4), 354-358.

Elansary, H. O., Salem, M. Z. M., Ashmawy, N. A., Yessoufou, K., and El-Settawy, A. A. A. (2017). "In vitro antibacterial, antifungal, and antioxidant activities of Eucalyptus spp. leaf extracts related to phenolic composition," Natural Product Research 31(24), 2927-2930. DOI: 10.1080/14786419.2017.1303698

El-Hefny, M., Abo Elgat, W. A. A., Al-Huqail, A. A., and Ali, H. M. (2019). "Essential and recovery oils from Matricaria chamomilla flowers as environmentally friendly fungicides against four fungi isolated from cultural heritage objects," Processes 7(11), 1-12. DOI: 10.3390/pr7110809

El-Hefny, M., Mohamed, A. A., Salem, M. Z. M., Abd El-Kareem, M. S. M., and Ali, H. M. (2018). "Chemical composition, antioxidant capacity and antibacterial activity against some potato bacterial pathogens of fruit extracts from Phytolacca dioica and Ziziphus spina-christi grown in Egypt," Scientia Horticulturae 233, 225-232. DOI: 10.1016/j.scienta.2018.01.046

El-Sabrout, A. M., Salem, M. Z. M., Bin-Jumah, M., and Allam, A. A. (2019). "Toxicological activity of some plant essential oils against Tribolium castaneum and Culex pipiens larvae," Processes 7(12), 1-24. DOI: 10.3390/pr7120933

Fadzir, U. A., Darnis, D. S., Mustafa, B. E., and Mokhtar, K. I. (2018). “Linum usitatissimum as an antimicrobial agent and a potential natural healer: A review," Archives of Orofacial Science 13(2), 55-62.

Fouad, H. A., and da Camara, C. A. G. (2017). "Chemical composition and bioactivity of peel oils from Citrus aurantiifolia and Citrus reticulata and enantiomers of their major constituent against Sitophilus zeamais (Coleoptera: Curculionidae),' Journal of Stored Products Research 73, 30-36. DOI: 10.1016/j.jspr.2017.06.001

Golmohammadi, M., Borghei, A., Zenouzi, A., Ashrafi, N., and Taherzadeh, M. J. 
(2018). "Optimization of essential oil extraction from orange peels using steam explosion," Heliyon 4(11), 1-18. DOI: 10.1016/j.heliyon.2018.e00893

Goyal, A., Sharma, V., Upadhyay, N., Gill, S., and Sihag, M. (2014). "Flax and flaxseed oil: An ancient medicine \& modern functional food," Journal of Food Science Technology 51(9), 1633-1653. DOI: 10.1007/s13197-013-1247-9

Guilloux, K., Gaillard, I., Courtois, J., Courtois, B., and Petit, E. (2009). "Production of arabinoxylan-oligosaccharides from flaxseed (Linum usitatissimum)," Journal of Agricultural and Food Chemistry 57(23), 11308-11313. DOI: 10.1021/jf902212z

Hall III, C., Tulbek, M. C., and Xu, Y. (2006). "Flaxseed," in: Advances in Food and Nutrition Research, S. L. Taylor (ed.), Elsevier, Amsterdam, Netherlands, pp. 1-97. DOI: 10.1016/S1043-4526(06)51001-0

Hamad, Y. K., Abobakr, Y., Salem, M. Z. M., Ali, H. M., Al-Sarar, A. S., and Al-Zabib, A. A. (2019). "Activity of plant extracts/essential oils against three plant pathogenic fungi and mosquito larvae: GC/MS analysis of bioactive compounds," BioResources 14(2), 4489-4511. DOI: 10.15376/biores.14.2.4489-4511

Hamada, H. M., Awad, M., El-Hefny, M., and Moustafa, M. A. M. (2018). "Insecticidal activity of garlic (Allium sativum) and ginger (Zingiber officinale) oils on the cotton leafworm, Spodoptera littoralis (Boisd.)(Lepidoptera: Noctuidae)," African Entomology 26(1), 84-94. DOI: 10.4001/003.026.0084

Hassan, R. R. A. (2016). "Thermal degradation of paper: the structure changes of fibres," Egyptian Journal of Archaeological and Restoration Studies 6(2), 71-84. DOI: 10.21608/ejars.2016.23543

Hassan R. R. A., and Mansour M. M. A. (2018). "A microscopic study of paper decayed by Trichoderma harzianum and Paecilomyces variotii," Journal of Polymers and the Environment 26(7), 2698-2707. DOI: 10.1007/s10924-017-1147-6

Hassan, R. R. A. (2015). "Behavior of archeological paper after cleaning by organic solvents under heat accelerated ageing," Mediterranean Archaeology and Archaeometry 15(3), 141-150. DOI: 10.5281/zenodo.18365

Hassan, R. R. A. (2019). "The restoration of two historic leather bindings according to a new strategy," Journal of the Institute of Conservation 42(3), 210-225. DOI: $10.1080 / 19455224.2019 .1654532$

Hassan, R. R. A. (2020). "In vitro study for use of cactus gel in enhancing the mechanical strengths of vegetable tanned leathers under accelerated aging," International Journal of Precision Engineering and Manufacturing 21, 145-155. DOI: 10.1007/s12541019-00178-X

Hassan, R. R. A. (2020). "Using Polaroid- zinc oxide nanocomposites in strengthening a historical printed paper: Application to "Annales Agricoles"- 1829 AD," Pigment \& Resin Technology, 49(5), 369-375. DOI: 10.1108/PRT-02-2020-0012

Hassan, R. R. A., Ali, M. F., Fahmy, A.-G. A., Ali, H. M., and Salem, M. Z. M. (2020). "Documentation and evaluation of an ancient paper manuscript with leather binding using spectrometric methods," Journal of Chemistry 2020, 1-10. DOI: $10.1155 / 2020 / 6847910$

Hassan, R. R. A., and Mohamed, W. S. (2017). "Effect of methyl methacrylate/ hydroxyethyl methacrylate copolymer on optical and mechanical properties and longterm durability of paper under accelerated ageing," International Journal of Conservation Science 8(2), 237-250. DOI: 10.1007/s00339-018-1989-3

Hong, J. H., Khan, N., Jamila, N., Hong, Y. S., Nho, E. Y., Choi, J. Y., Lee, C. M., and Kim, K. S. (2017). "Determination of volatile flavour profiles of Citrus spp. fruits by 
SDE-GC-MS and enantiomeric composition of chiral compounds by MDGC-MS," Phytochemical Analysis 28(5), 392-403. DOI: 10.1002/pca.2686

Hussein, H. S., Salem, M. Z. M., and Soliman, A. M. (2017). "Repellent, attractive, and insecticidal effects of essential oils from Schinus terebinthifolius fruits and Corymbia citriodora leaves on two whitefly species, Bemisia tabaci, and Trialeurodes ricini," Scientia Horticulturae 216, 111-119. DOI: 10.1016/j.scienta.2017.01.004

Ibrahim, F. A., Usman, L. A., Akolade, J. O., Idowu, O. A., Abdulazeez, A. T., and Amuzat, A. O. (2019). "Antidiabetic potentials of Citrus aurantifolia leaf essential oil,” Drug Research 69(4), 201-206. DOI: 10.1055/a-0662-5607

Kaithwas, G., and Majumdar, D. K. (2013). "Effect of L. usitatissimum (flaxseed/linseed) fixed oil against distinct phases of inflammation," International Scholarly Research Notices, 735158. DOI: 10.1155/2013/735158

Kaithwas, G., Mukerjee, A., Kumar, P., and Majumdar, D. K. (2011). “Linum usitatissimum (linseed/ flaxseed) fixed oil: Antimicrobial activity and efficacy in bovine mastitis," Inflammopharmacology 19(1), 45-52. DOI: 10.1007/s10787-010-0047-3

Kamel, S., El-Sakhawy, M., and Nada, A. M. A. (2004). "Mechanical properties of the paper sheets treated with different polymers," Thermochimica Acta 421(1-2), 81-85. DOI: 10.1016/j.tca.2004.03.005

Khattab, M. A., El-Ashael, A. A., and Kandil, S. H. (1999). "Effect of contamination of cotton fabric with linseed oil on the activation energies of pyrolysis and oxidation of the fabric," Fire Materials 23(3), 131-137. DOI: 10.1002/(SICI)10991018(199905/06)23:3<131::AID-FAM678>3.0.CO;2-4

Krajčová, A., Schulzová, V., Hajšlová, J., and Bjelková, M. (2009). "Lignans in flaxseed," Czech Journal of Food Sciences 27(S1), 252-255. DOI: 10.17221/1062CJFS

Ljaljević-Grbić, M., Stupar, M., Vukojević, J., Maričić, I., and Bungur, N. (2013). "Molds in museum environments: biodeterioration of art photographs and wooden sculptures," Archives of Biological Sciences, 65(3), 955-962. DOI: $10.2298 / \mathrm{abs} 1303955 \mathrm{~g}$

Le Moigne, N. (2008). Swelling and Dissolution Mechanisms of Cellulose Fibres, Ph.D. Dissertation, École Nationale Supérieure des Mines de Paris, Paris, France.

Lemes, R. S., Alves, C. C. F., Estevam, E. B. B., Santiago, M. B., Martins, C. H. G., Santos, T. C. D., Crotti, A. E. M., and Miranda, M. L. D. (2018). "Chemical composition and antibacterial activity of essential oils from Citrus aurantifolia leaves and fruit peel against oral pathogenic bacteria," Anais da Academia Brasileira de Ciências 90(2), 1285-1292. DOI: 10.1590/0001-3765201820170847

Madera-Santana, T. J., Aguilar-Vega, M. J., Márquez-Lucero, A., and Vázquez-Moreno, F. (2002). "Production of leather-like composites using chemically modified short leather fibers. I: Chemical modification by emulsion polymerization," Polymer Composites 23(1), 49-60. DOI: 10.1002/pc.10411

Mansour, M. M. A., EL-Hefny, M., Salem, M. Z. M., and Ali, H. M. (2020a). "The biofungicide activity of some plant essential oils for the cleaner production of model linen fibers similar to those used in ancient Egyptian mummification," Processes 8(1), 1-19. DOI: 10.3390/pr8010079

Mansour, M. M. A., Hamed, S. A. E.-K. M., Salem, M. Z. M., and Ali, H. M. (2020b). "Illustration of the effects of five fungi on Acacia saligna wood organic acids and ultrastructure alterations in wood cell walls by HPLC and TEM examinations," Applied Sciences 10(8), 1-14. DOI: 10.3390/app10082886 
Massoud, M. A., Saad, A. S. A., Soliman, E. A., and El-Moghazy, A. Y. (2012). "Antifungal activity of some essential oils applied as fumigants against two stored grains fungi," J. Adv. Agric. Res. (Fac Agric Saba Basha), 17(2), 296-306.

Matasyoh, J. C., Kiplimo, J. J., Karubiu, N. M., and Hailstorks, T. P. (2007). “Chemical composition and antimicrobial activity of essential oil of Tarchonanthus camphorates," Food Chemistry 101(3), 1183-1187. DOI: 10.1016/j.foodchem.2006.03.021

Mohamed, A. A., Behiry, S. I., Ali, H. M., EL-Hefny, M., Salem, M. Z. M., and Ashmawy, N. A. (2020a). "Phytochemical compounds of branches from $P$. halepensis oily liquid extract and S. terebinthifolius essential oil and their potential antifungal activity," Processes 8(3), 1-18. DOI: 10.3390/pr8030330

Mohamed, A. A., El-Hefny, M., El-Shanhorey, N. A., and Ali, H. M. (2020b). "Foliar application of bio-stimulants enhancing the production and the toxicity of Origanum majorana essential oils against four rice seed-borne fungi," Molecules 25(10), 1-19. DOI: $10.3390 /$ molecules25102363

Moufida, S., and Marzouk, B. (2003). "Biochemical characterization of blood orange, sweet orange, lemon, bergamot and bitter orange," Phytochemicals 62(8), 1283-1289. DOI: 10.1016/S0031-9422(02)00631-3

Mueller, K., Eisner, P., Yoshie-Starc, Y., Nakada, R., and Kirchhoff, E. (2010). "Functional properties and chemical composition of fractionated brown and yellow linseed meal (Linum usitatissimum L.)," Journal of Food Engineering 98(4), 453-460. DOI: 10.1016/j.jfoodeng.2010.01.028

Narang, N., and Jiraungkoorskul, W. (2016). "Anticancer activity of key lime, Citrus aurantifolia," Pharmacognosy Reviews 10(20), 118-122. DOI: 10.4103/09737847.194043

Narender, B. R., Tejaswini, S., Sarika, M., Karuna, N., Shirisha, R., and Priyanka, S. (2016). "Antibacterial and antifungal activities of Linum usitatissimum (flax seeds)," International Journal of Pharmacy Education and Research 3(2), 4-8.

Nasr, H. E., and Ismail, A. (2010). "Improving the leather performance via treatment with different adducts and grafting with 1-vinyl-2-pyrrolidinone," New York Science Journal 3(9), 112-119.

Okla, M. K., Alamri, S. A., Alatar, A. A., Hegazy, A. K., Al-Ghamdi, A. A., Ajarem, J. S., Faisal, M., Abdel-Salam, E. M., Ali, H. M., Salem, M. Z. M., et al. (2019a). "Antioxidant, hypoglycemic, and neurobehavioral effects of a leaf extract of Avicennia marina on autoimmune diabetic mice," Evidence-Based Complementary and Alternative Medicine 2019, 1-8. DOI: 10.1155/2019/1263260

Okla, M. K., Alamri, S. A., Salem, M. Z. M., Ali, H. M., Behiry, S. I., Nasser, R. A., Alaraidh, I. A., Al-Ghtani, S. M., and Soufan, W. (2019b). "Yield, phytochemical constituents, and antibacterial activity of essential oils from the leaves/twigs," branches, branch wood, and branch bark of Sour Orange (Citrus aurantium L.). Processes 7(6), 1-15. DOI: 10.3390/pr7060363

Paiva, P. M. G., Gomes, F. S., Napoleão, T. H., Sá, R. A., Correia, M. T. S., and Coelho, L. C. B. B. (2010). "Antimicrobial activity of secondary metabolites and lectins from plants," in: Current Research, Technology and Education Topics in Applied Microbiology and Microbial Biotechnology, A. Méndez-Vilas (ed.), Formatex Research Center, Badajoz, Spain, pp. 396-406.

Pathan, R. K., Gali, P. R., Pathan, P., Gowtham, T., and Pasupuleti, S. (2012). "In vitro antimicrobial activity of Citrus aurantifolia and its phytochemical screening," Asian 
Pacific Journal of Tropical Disease 2(1), 328-331. DOI: 10.1016/S22221808(12)60176-5

Pinheiro, A. C., Sequeira, S. O., and Macedo, M. F. (2019). "Fungi in archives, libraries, and museums: a review on paper conservation and human health," Critical Reviews in Microbiology, 45(5-6), 686-700. DOI: 10.1080/1040841X.2019.1690420

Piper, P., Calderon, C. O., Hatzixanthis, K., and Mollapour, M. (2001). "Weak acid adaptation: The stress response that confers resistance to organic acid food presservatives," Microbiology 147(10), 2635-2642. DOI: 10.1099/00221287-147-10-2635

Popa, V.-M. , Gruia, A., Raba, D.-N., Dumbrava, D., Moldovan, C., Bordean, D., and Mateescu, C. (2012). "Fatty acids composition and oil characteristics of linseed (Linum usitatissimum L.) from Romania," Journal of Agroalimentary Processes and Technologies 18(2), 136-140.

Rammanee, K., and Hongpattarakere, T. (2011). "Effects of tropical citrus essential oils on growth, aflatoxin production, and ultrastructure alterations of Aspergillus flavus and Aspergillus parasiticus," Food and Bioprocess Technology 4(6), 1050-1059. DOI: 10.1007/s11947-010-0507-1

Razzaghi-Abyaneh, M., Shams-Ghahfarokhi, M., Rezaee, M.-B., Jaimand, K., Alinezhad, S., Saberi, R., and Yoshinari, T. (2009). "Chemical composition and antiaflatoxigenic activity of Carum carvi L., Thymus vulgaris and Citrus aurantifolia essential oils," Food Control 20(11), 1018-1024. DOI: 10.1016/j.foodcont.2008.12.007

Rudnik, E., Szczucinska, A., Gwardiak, H., Szulc, A., and Winiarska, A. (2001) "Comparative studies of oxidative stability of linseed oil," Thermochimica Acta 370(1-2), 135-140. DOI: 10.1016/S0040-6031(00)00781-4

Salem, M. Z. M., Zayed, M. Z., Ali, H. M., and Abd El-Kareem, M. S. M. (2016a). "Chemical composition, antioxidant and antibacterial activities of extracts from Schinus molle L. wood branch growing in Egypt," Journal of Wood Science 62(6), 548-561. DOI: 10.1007/s10086-016-1583-2

Salem, M. Z. M., Zidan, Y. E., Mansour, M. M. A., El Hadidi, N. M. N., and Abo Elgat, W. A. A. (2016b). "Antifungal activities of two essential oils used in the treatment of three commercial woods deteriorated by five common mold fungi," International Biodeterioration \& Biodegradation 106(1), 88-96. DOI: 10.1016/j.ibiod.2015.10.010

Salem, M. Z. M., Mansour, M. M. A., Mohamed, W. S., Ali, H. M., and Hatamleh, A. A. (2017). "Evaluation of the antifungal activity of treated Acacia saligna wood with Paraloid B-72/ $\mathrm{TiO}_{2}$ nanocomposites against the growth of Alternaria tenuissima, Trichoderma harzianum, and Fusarium culmorum," BioResources 12(4), 7615-7627. DOI: 10.15376/biores.12.4.7615-7627

Salem, M. Z. M., Behiry, S. I., and EL-Hefny, M. (2019a). "Inhibition of Fusarium culmorum, Penicillium chrysogenum and Rhizoctonia solani by n-hexane characterized extracts of three plant species as a wood-treated oil-fungicide model," Journal of Applied Microbiology 126(6), 1683-1699. DOI: 10.1111/jam.14256

Salem, M. Z. M., Hamed, S. A. E.-K. M, and Mansour, M. M. A. (2019b). “Assessment of efficacy and effectiveness of some extracted bio-chemicals as bio-fungicides on wood," Drvna Industrija 70(4), 337-350. DOI: 10.5552/drvind.2019.1837

Salem, M. Z. M., Abo Elgat, W. A. A., Taha, A. S., Fares, Y. G. D., and Ali, H. M. (2020a). "Impact of three natural oily extracts as pulp additives on the mechanical, optical, and antifungal properties of paper sheets made from Eucalyptus camaldulensis and Meryta sinclairii wood branches," Materials 13(6), 1-27. DOI: 10.3390/ma13061292 
Salem, M. Z. M., Ali, M. F., Mansour, M. M. A., Ali, H. M., Abdel Moneim, E. M., and Abdel-Megeed A. (2020b). "Anti-termitic activity of three essential oils, chlorpyrifos, and a bioagent compound (Protecto) against termite Microcerotermes eugnathus Silvestri (Isoptera: Termitidae) in Egypt," Insects 11(11), 756. DOI: 10.3390/insects11110756

Salem, M. Z. M., Ibrahim, I. H., Ali, H. M., and Helmy, H. M. (2020c). “Assessment of the use of natural extracted dyes and pancreatin enzyme for dyeing of four natural textiles: HPLC analysis of phytochemicals," Processes 8, 59.

DOI:10.3390/pr8010059

Salim, E., Abdel-Hamied, M., Salim, S., Gamal, S., Mohamed, S., Galal, F. E.-Z., Tarek, F., Hassan, R. R. A., Ali, H. M., and Salem, M. Z. M. (2020). "Reduction of borax / agar-based gel residues used to neutralize acidity of a historical manuscript with use of different paper barriers: Artificial ageing results," BioResources 15(3), 6576-6599. DOI: 10.15376/biores. 15.3.6576-6599

SAS (2001). User Guide: Statistics (Release 8.02), SAS Institute, Cary, NC.

Seidel, V., and Taylor, P. W. (2004). "In vitro activity of extracts and constituents of Pelagonium against rapidly growing mycobacteria," International Journal of Antimicrobial Agents 23(6), 613-619. DOI: 10.1016/j.ijantimicag.2003.11.008

Sequeira, S. O., Cabrita, E. J., and Macedo, M. F. (2014). "Fungal biodeterioration of paper: How are paper and book conservators dealing with it?," Restaurator. International Journal for the Preservation of Library and Archival Material 35(2), 181-199. DOI: 10.1515/rest-2014-0005

Shim, Y. Y., Gui, B., Arnison, P. G., Wang, Y., and Reaney, M. J. T. (2014). "Flaxseed (Linum usitatissimum L.) bioactive compounds and peptide nomenclature: A review," Trends in Food Science \& Technology 38(1), 5-20. DOI: 10.1016/j.tifs.2014.03.011

Simopoulos, A. P. (2002). "The importance of the ratio of omega-6/omega-3 essential fatty acids," Biomedicine \& Pharmacotherapy 56(8), 365-379. DOI: 10.1016/S07533322(02)00253-6

Soković, M., and van Griensven, L. J. L. D. (2006). “Antimicrobial activity of essential oils and their components against the three major pathogens of cultivated button mushroom Agaricus bisporus," European Journal of Plant Pathology 116, 211-224. DOI: $10.1007 / \mathrm{s} 10658-006-9053-0$

Spadaro, F., Costa, R., Circosta, C., and Occhiuto F. (2012). "Volatile composition and biological activity of Key lime Citrus aurantifolia essential oil," Natural Product Communications 7(11), 1523-1526. DOI: 10.1177/1934578X1200701128

Tundis, R., Loizzo, M. R., Bonesi, M., Menichini, F., Mastellone, V., Colica, C., and Menichini, F. (2012). "Comparative study on the antioxidant capacity and cholinesterase inhibitory activity of Citrus aurantifolia Swingle, C. aurantium L., and C. bergamia Risso and Poit. peel essential oils," Journal of Food Science 77(1), 4046. DOI: 10.1111/j.1750-3841.2011.02511.x

Velázquez-Nuñez, M. J., Avila-Sosa, R., Palou, E., and López-Malo, A. (2013). "Antifungal activity of orange (Citrus sinensis var. Valencia) peel essential oil applied by direct addition or vapor contact," Food Control 31(1), 1-4. DOI: 10.1016/j.foodcont.2012.09.029

Viuda-Martos, M., Ruiz-Navajas, Y., Fernández-López, J. and Pérez-Álvarez, J. (2008). "Antifungal activity of lemon (Citrus lemon L.), mandarin (Citrus reticulata L.), grapefruit (Citrus paradisi L.) and orange (Citrus sinensis L.) essential oils," Food Control 19(12), 1130-1138. DOI: 10.1016/j.foodcont.2007.12.003 
Wang, Z.-J., Liang, C.-L., Li, G.-M., Yu, C.-Y., and Yin, M. (2007). "Stearic acid protects primary cultured cortical neurons against oxidative stress 4," Acta Pharmacologica Sinica 28(3), 315-326. DOI: 10.1111/j.1745-7254.2007.00512.x

$\mathrm{Xu}, \mathrm{Y}$., Hall III, C., and Wolf-Hall, C. (2008). "Antifungal activity stability of flaxseed protein extract using response surface methodology," Journal of Food Science 73(1), 9-14. DOI: 10.1111/j.1750-3841.2007.00576.x

Xu, Y., Hall III, C., Wolf-Hall, C., and Manthey, F. (2008). "Fungistatic activity of flaxseed in potato dextrose agar and a fresh noodle system," International Journal of Food Microbiology 121(3), 262-267. DOI: 10.1016/j.ijfoodmicro.2007.11.005

Youssef, A. M., Kamel, S., El-Sakhawy, M., and El Samahy, M. A. (2012). "Structural and electrical properties of paper-polyaniline composite," Carbohydrate Polymers 90(2), 1003-1007. DOI: 10.1016/j.carbpol.2012.06.034

Zyani, M., Mortabit, D., Mostakim, M., Iraqui, M., Haggoud, A., Ettayebi, M., and Koraichi, S. I. (2009). "Cellulolytic potential of fungi in wood degradation from an old house at the Medina of Fez," Annals of Microbiology 59(4), 699-704. DOI: 10.1007/BF03179211

Article submitted: Sept. 18, 2020; Peer review completed: Nov. 15, 2020; Revised version received and accepted: November 22, 2020; Published: November 24, 2020. DOI: $10.15376 /$ biores.16.1.492-514 